\title{
The Indispensability of Education Technology in Modern Jingdezhen Ceramic
}

\author{
Xiumei Wu \\ University of Jingdezhen ceramic institute of design art, Jingdezhen 333403, China
}

Keywords: Jingdezhen, ceramic education, recovery.

\begin{abstract}
Modern porcelain of jingdezhen ceramic art from the traditional family inheritance system gradually transition to the ceramic school to teach, this is not going to do.
\end{abstract}

\section{Introduction}

First, the Chinese people realize the importance of education, advocate science and technology and aesthetic education and rejuvenating the country. Westernization movement period, li hongzhang, zuo zongtang, zhang zhidong and others thought that it would be a "rich" and "power", to technology development, technology and development is the key role of talent cultivation. The article published in April 1912, CAI yuanpei, on the opinions of the relevant education policies, he emphasized aesthetic education and rejuvenating the country, think drawing class, and handicraft class are the basis of aesthetic education rise. He said: "the picture, and aesthetic education, and its content includes various, such as physical picture of materialism, history painting of $\mathrm{Yu}$ Deyu. Even to the dignity of the beautiful object, you can get world view." "Manual, materialism also, also can beauty." Modern government after the establishment, a series of reform of the education, in its reform, attention to the fine arts education especially, manual painting is on the agenda. Jingdezhen ceramic handmade painting education in national education reform has been under the background of the rise of comprehensive.

Second, China's porcelain industry school, began in the late westernization movement - guangxu twenty-two years (1896), the liangjiang governor zhang zhidong's then in the high Jiang Xishen please do small steam, porcelain and silkworm academy fold ", referred to as a matter of contented industry school for the first time. But during the qing dynasty in the troubled times, just the defeat of the war, the paid reparations to Japan, the qing court was burned, is really busy school things. And then the failure of wuxu reform movement, colonial invasions of China, to start a contented industry school of motion. Until 1910, when China's national capitalism began to awaken, they feel that the long feudal social relations and the walls of small-scale production seriously hindered the progress of China industry, "conventional tradition and modern times jingdezhen porcelain making way also can't fight against YangCi, so the industry must be improved. The improved besides run industries, the most important thing is to cultivate talent new industry. So, jiangxi province, jingdezhen porcelain industry company general manager business association's first prime minister kangda, petition approval department, joint zhili province, hubei, jiangsu, anhui provinces such as collaborative venture founded the first in the history of Chinese ceramics vocational schools - school ability of Chinese contented industry.

\section{The introduction of new machines need large Numbers of ceramic professionals}

Growing in modern times, the new economic factors, new science, new technology emerge in endlessly, plus YangCi intrusion, has led many to recognize the importance of the mechanical system porcelain, ceramic capitalists so have introduced all kinds of ceramic machinery equipment. But the mass production of large industrial scale compared with traditional handicraft industry, the requirement of technology and design is much higher. First of all, a huge number of mechanical production of ceramic products so if some small errors in design and manufacturing porcelain industry 
losses will be very great; Second, porcelain production and market at home and abroad, the machine production is irreversible, and so on, before production is required in advance design, the production of ceramic products after complete design, party can start production. Again, the design and manufacture of traditional manual ceramic are performed by one person or a minority, they for the design and production process is very familiar with, but in the modern industrial production system, the designer and producer is separated, so stylist in the design, also need porcelain making auxiliary to learn and be familiar with production process, otherwise it is possible to produce defective products.

In modern times, China professionals is lack, so some manufacturers only to large amounts of imported ceramic design drawings, but buy the patterns of the samples, on the one hand, is not suitable for Chinese people's aesthetic requirements; On the other hand, because of the great cost greatly increased the cost of production, lead to less competitive in foreign goods of jingdezhen porcelain, also makes our country ceramics handicraft production had been everywhere. So, the demand for ceramics design professionals to make some people recognize that strengthen domestic ceramic design talented person's raise is imminent.

Recognising that rise and fall of porcelain industry, some people naturally put ceramic professional education in the important place to develop. For ceramic vocational education can the degree is low and lack of expertise of unemployed groups are short and the effective training, so that they can be used for the ceramic development quickly, also is helpful to solve the problem of their livelihoods. Porcelain industry school professor content easy to learn, just beginning ability is strong, such as porcelain molding, simple pattern design and drawing, etc. In addition, the ceramic profession education can also according to the need of society and adjust training method. Between the above reasons, the ceramic profession education naturally become one of the main ways to develop ceramic designers.

Visible, in the modern period of jingdezhen ceramic vocational school is founded since ancient times in the history of Chinese ceramics is not some initiative, not only for early modern ceramic made certain contribution to the development, but also to the development of jingdezhen porcelain industry of the People's Republic of China has trained a large number of professional talents. Introduce the result of science and technology, on the one hand, performance in promoting productivity, on the other hand also inevitably brings about the impact of social thought and change. In modern times, some western science and technology in China were translated and published books, these books are rich in ceramics from personnel of course of process knowledge at the same time, further broadened their horizons, update their concept of industry development. The government has also sent a large number of students at public expense to accept western science and technology knowledge and ideas. These young well, after returning from the open lecture hall or start school in succession, will learn to impart the knowledge and skills while studying more Chinese people, such as China's famous ceramics and ceramic educator - Wang Fan, life has close relationship with ceramics, ceramic production and the education of our country, made a lot of pioneering work. Such as Du Chongyuan again, after returning to China in 1923 to open zhaoqing ceramics company in shenyang, he advocated industrial salvation, after to jingdezhen and ShiYeBu XiangEGan area survey Chen Xiaona together at jingdezhen porcelain making, director of the situation, and put forward the development of jingdezhen porcelain struggling in the top ten reasons. He advocated to set up the mechanism of large-scale ceramic factory, with ShiYeBu XiangEGan Chen Xiaona make joint, director of the survey area ten big improvement measures. Ten big improvement measures are mentioned in the opening contented industry school, universal education workers and students to study abroad new technology, the introduction of new equipment. These students, together with the influx of science and technology books introducing concept of western modern science and technology and China, aroused the enthusiasm of the Chinese people to accept the modern science and technology education.

The introduction of western modern porcelain making technology and use, makes the traditional way of the cultivation of the porcelain making craftsmen already can not adapt to the development of porcelain making machine needs. On the one hand, porcelain making machine needs a large number of skilled workers master the machine operation, the traditional way of teacher and pupil inheritance can 
only meet the demand of tiny quantity; , on the other hand, focuses on the traditional porcelain making education the teaching of practical skills, but the mechanical system porcelain requires not only technical workers should have strong ability of practice, but also have a certain cultural knowledge and artistic appreciation ability, the only through modern vocational education to achieve.

\section{The industrial rise of the national salvation movement advocated to cultivate new talent}

As early as the period of westernization movement li hongzhang, zuo zongtang, zhang zhidong, they learned to "rich" and "power", must want to technology development, technology and development, and the key for the development of technology, the function of the talent is very huge. Zhang zhidong had said: "China is not poor in wealth, and those in the talent", said: "China tries to self-improvement, cultivating talents and no hands." After the revolution, the capitalist ideology in the social from all walks of life to spread, "science" and "democratic" point of view gradually into the heart, for the development of Chinese modern education provides a better environment. In modern times, economic growth, technological leap, and foreign pressure, makes all aspects of the talents is very scarce. National capitalists have realize the importance of mechanical production, so have introduced mechanical porcelain making equipment. However, the large industrial scale production compared with the traditional craft porcelain, is much more to the requirement of design, as a result, the cultivation of porcelain making talent is urgently needed. Huang yanpei after investigation of jingdezhen in 1914, in the diary study education puts it: "the system of jingdezhen porcelain, already hold method cannot be modified, and afraid to once modified, will be eliminated, and without her meal, due to fit in with the boycott is one of the potential," off-site to avoid the mine.

\section{Ceramic art education reform promoted by civil wars}

The bourgeois revolution led by sun yat-sen in 1911, destroyed the decayed qing dynasty, established a bourgeois republic. But because of its weak compromise, the Chinese bourgeois republic regime soon turn into the hands of the feudal warlord yuan shikai. The northern warlords during the reign of the darkest and most chaotic period in China's modern history, 16 years, the national long-term in a state of war. Until after the outbreak of the Anti-Japanese War, due to the draft, began to open a training course in the school, elementary school and junior high school have scouts, high school and college military training. Because of the lack of a stable and clear political environment, jingdezhen contented industry school forced demolition and relocation, several times makes students not rest, slow development of education cause industry. Such as in the years 1939 to 1942, jingdezhen continuously by the enemy bombing, schools, factories were razed to the ground everywhere, people have to go out in the morning to the country or the mountains, to avoid back home in the evening. In such an environment, and who has a mind sitting in the classroom learning ceramic technology, the education sector, is undoubtedly a misfortune of The Times.

Visible, porcelain industry school although established, but the progress and development of ceramic school education, and the social environment is closely related to the age. Stable environment promote the development of ceramic education and turbulent environment block ceramic education progress.

\section{Innovation of ideological concept}

Jingdezhen porcelain industry production, is a typical way of handicraft production, there are a lot of limitations, the workers of the feudal thought is very serious. Thus to improve production technology and process, it is not happen overnight. Aiming at the situation of the time, administration guide skilled workers for the new thought, constantly reinvent their old feudal ideas. Especially saggar plant, mold shop, red line, porcelain, chau shop as well as the so-called "five elements" (color, eight piles, packaging, barrel, dozen winding) and other industries the father the son, the son in the sun's hereditary convention in deep of their thoughts. Because so they can dominate the industry, once 
removed, buying and selling is free, the market is no longer controlled by them, for those who like this would be a great loss. Administration of contented industry after the founding of the rectification, first lift the hereditary, and as the porcelain industry school, set up the system porcelain craft gradually into learning to transmit through the school. On the one hand, the porcelain industry school employ old master to lecture to the salary, let them leave their teaching; , on the other hand, by giving them the knowledge, give them to instill new ideas, make them aware of the coming through to teach students the skills can also have a source, only passing down the next generation to make his own craft porcelain more development.

Contented industry administration has canceled many other walls, makes the phenomenon of the monopoly market no longer before, let them realize that only industries together can better promote the development of industry, to break the YangCi blunt will describe the situation of the domestic market.

Change also ceramics workers thought on the lifting they used to think of the idea of "innocence is the virtue for women", think reading is a man, a woman must obey "wifely submission and virtue" of feudal ideas. Such as feng jiu ge in jingdezhen "bead mountain" the biggest difficulty is encountered in the process of girls can't read the feudal thought, the feudal thought the most stubborn is the potter, so feng jiu ge to persuade them. Whenever festival holiday party by fellow, feng jiu ge unto them in all events at home and abroad, developed city prosperous situation, inspired they know education can promote scientific development, can make the ceramic industry prosper; Encourage them to send their children to school, emphasizing the daughter like a man, should also be reading, also for our fathers, from their experiences and make them realize the harm of son preference and illiterate.

Porcelain making workers the transformation of ideas, for the development of jingdezhen porcelain is undoubtedly a very beneficial.

\section{The introduction of western science and technology education}

By the end of the qing dynasty in modern times, China's political and social outlook has undergone earth-shaking changes, the commodity economy development to a new level. In the intense and profound social change, jingdezhen porcelain industry education from education idea, or a way of knowledge transfer, personnel training target, etc., have undergone a modern change.

Western concept of education is to advocate science and technology and rejuvenating the country, only the development of science and technology can make the development of the economy. Western concept of the education of science and technology was introduced into China, on the one hand, as the invasion of western business steps, on the other hand is back by students, and step by step into the Chinese education idea at that time.

Technology in the whole world ideas are of profound changes caused with the development of industry and commerce at the same time, the education idea the introduction of new industry inevitably produce very big effect to the traditional manual porcelain. As Mr Zhang hao returned from studying in Tokyo, Japan, the province and Mr Kangda founded in 1910 in the province Yang county ceramics with school. Ceramic industry school encourages students to study western science and technology, the new porcelain making method, to the revitalization of Chinese porcelain. At a time when jingdezhen feudal forces, the idea that the jingdezhen porcelain has always been the world's first, handmade porcelain is better than mechanical porcelain making, especially the older generation of craftsmen can't accept the mechanical system porcelain. So the school can't do in jingdezhen, had to save and jointly by several provinces names is China ceramic industry school. By visible on the traditional feudal ideas and students come back with new ideas is the original. It is difficult to take root in jingdezhen contented industry school, new ideas of Chinese and western need a running-in process. Only a mix of Chinese and western to jingdezhen ceramic education into a new stage. Such as after the xinhai revolution, contented industry type changed to jiangxi industrial schools. Mr Zhang hao to the principal, and in jingdezhen never put off till tomorrow what you can get a branch, training technical personnel. Visible, when people's minds have been quietly. Porcelain industry school gradually 
expanding and development, the development of jingdezhen porcelain industry has played a certain role in promoting.

In addition, the western education idea advocated everyone has the right to enjoy education, women can also enter the school to accept education. And this is it won't work in China's feudal society, the traditional Chinese education is education only men, women are women, family status, underground didn't accept the school education and the opportunity to learn cultural knowledge. This kind of education concept has been bound with the development of education in China. Jingdezhen as a relatively closed town, thought is relatively more conservative, the porcelain making skill is always preach man not female. Porcelain industry school after opening, influenced by the western education, women also have the right to accept education into the school. This is a breakthrough in modern times jingdezhen ceramic education, the development of jingdezhen porcelain played a great promoting role.

At the same time of western technology was introduced into the domestic, some western advanced education mode is also introduced. Because traditional Chinese porcelain making technology in modern before into the formal school education, while western education form once introduced, becomes the Chinese education model to follow. Jingdezhen ceramic education also draw lessons from this new form of education, for the later modern transformation of Chinese ceramic education pattern played a great demonstration effect.

Western science and technology education pays attention to is the combination of theory and practice, especially in terms of technology, theory and practice are inseparable. This kind of education mode to the introduction of ceramic that the technology has played a great role in promoting. In practice, the improvement of traditional porcelain making technology, can be said to be the western new technology and the product of the combination of school education and experiment. Zhang hao has to study in Japan to learn ceramics, back through the school, do a pilot plant, the introduction of burning coal pedal jigger, manually crushed glaze brush machine, printing, flower, plaster cast slab and other new technology, and application of these new technologies to practice, make traditional jingdezhen porcelain industry opened the prelude of modern production. Theoretically speaking, for the porcelain making technology of education is not only a porcelain making practical learning, but also in the fields of theory study, in theory to guide practice. Thus, Chinese education model attempts to introduce western industry for remote mountainous area of jingdezhen nots allow to ignore.

Nutshell, jingdezhen ceramic art as a long history of traditional craftsmanship, is always to the father the son in China, ACTS on the division way of inheritance. But since the early years of the modern capitalism economy development, the introduction of foreign advanced machinery and technology, the emergence of a new mode of production, there is a lot of can adapt mechanization production workers. Therefore, traditional father and son, ACTS on division skill inheritance patterns, he gradually won't work, since the and of generation is the new education mode to develop ceramic technology talents, pottery and porcelain of the establishment of vocational schools is catered to the new talents training mode, that is the preliminary of jingdezhen ceramic education reform.

To sum up, the modern jingdezhen ceramic education has tend to rationalize, step by step and through a variety of different types to try the way of teaching, gradually manifests the characteristic of diversification. Although most try is in its infancy, but it laid the foundation for the modern advanced ceramic education. Due to the interference by many factors such as social economy, politics, the development of the ceramic education also has to be desired, but its development process has trained many ceramic professionals, to some extent also promoted the reform and development of ceramic, for today's ceramic art education reform provides a rich valuable experience. Such as the 1910 nanyang kangyou porcelain body die and refractory chao deng award. And the cultivation of kangda "diligence and technology talents" educational philosophy, also the reference for future generations, and carry forward. 


\section{Conclusion}

Sum up and promote the cause of the rapid development of jingdezhen ceramic education mainly include: first, the early modern, a batch of western thought influence of contented industry personnel with strong national sense of responsibility and keen insight, the development of social change their deep understanding to, the revitalization of saving the nation from subjugation, must begin from economic development, and to develop the economy first in cultivating talents. They aimed at rescuing, dedicated to new start; Second, jingdezhen local government support for the new school founded provides more powerful political guarantee; Third, the collapse of imperial plant, a number of scattered folk craftsmen, with superb artistry porcelain industry school by hiring them, porcelain art practice course of the school professor provides senior technical talent, led to the heritage and development of traditional porcelain making skills.

\section{Acknowledgements}

Xiu-mei wu, female, doctor of design art, in fuzhou, master instructor, research direction: the art of design principle, industrial design and theory, ceramic art design and theory.

This paper is the jingdezhen ceramics university center for collaborative project: "jingdezhen ceramic art education from the evolution of modern times to contemporary".

\section{References}

[1] Xiu-mei wu: The evolution of the jingdezhen ceramic education from modern times to the modern, nanchan, Jiangxi fine arts publishing house, 2016.11.

[2] Xiu-mei wu: the inheritance and change - jingdezhen porcelain development research of the republic of China, Beijing, guangming daily press, 2012, 5.

[3] Xiu-mei wu: the traditional handicraft culture research - ceramic hangzhou fan, for example, Beijing: guangming daily press, 2013, 5.

[4] Zhen-fan wan, Lin Songhua editor: studies of modern times social transformation in jiangxi, Beijing: China social sciences press, 2001.

[5] XiChuan performance: "the classical works of design art anthology, nanjing: southeast university press, 2002. 